\title{
大規模並列計算に適した階層型直交メッシュ法 による完全オイラー型固体-流体連成解析
}

\author{
西口 浩司 ${ }^{1}$ ・バレラフール ${ }^{2}$ ・岡澤 重信 ${ }^{3}$ ・坪倉 誠 ${ }^{4}$ \\ 1 博士 (工学) 特別研究員 理化学研究所 計算科学研究機構（ $\bar{T}$ 650-0047 兵庫県神戸市中央区港島南町 7-1-26) \\ E-mail: koji.nishiguchi@ riken.jp \\ ${ }^{2} \mathrm{Ph} . \mathrm{D}$. 特別研究員 理化学研究所 計算科学研究機構（ $\bar{T} 650-0047$ 兵庫県神戸市中央区港島南町 7-1-26) \\ E-mail: rahul.bale@ riken.jp \\ ${ }^{3}$ 博士 (工学) 山梨大学教授大学院総合研究部 工学域 機械工学系 ( $\mathbf{T}$ 400-8511 山梨県甲府市武田 4-3-11) \\ E-mail: sokazawa@yamanashi.ac.jp \\ 4博士 (工学) チームリーダー 理化学研究所 計算科学研究機構 ( $\bar{T}$ 650-0047 兵庫県神戸市中央区港島南町 7-1-26), \\ 神戸大学教授大学院システム情報学研究科 計算科学専攻（７ 657-8501 兵庫県神戸市灘区六甲台 1-1） \\ E-mail: mtsubo@riken.jp
}

\begin{abstract}
本論文では, 複雑な形状を有する固体と流体の大規模な連成解析を可能とするため, メッシュの局所的細分 化が可能で並列化効率に優れたビルディングキューブ法による完全オイラー型固体-流体連成解析法を提案する. 基礎方程式として, 非圧縮性の仮定の下で固体と流体の基礎方程式を各物質の体積率を用いて体積平均化した 方程式を用いる。この基礎方程式はフラクショナル・ステップ法により速度場と圧力場に分離され，コロケー 卜変数配置法に基づく有限体積法で離散化される. 物質界面はVOF 法により捕捉される. そして，キャビティ 流れ中の円盤の 2 次元変形問題, および流体中で複雑形状を有する固体（Stanford bunny）を変形させる問題を 通じて，提案手法の妥当性を検証する.
\end{abstract}

Key Words: fluid-structure interaction, hyperelastic solid, building cube method, large-scale parallel computing

\section{1. 諸言}

固体-流体連成解析では，流体はオイラー型解法で計 算されるのに対して，固体はラグランジュ型解法または arbitrary Lagrangian-Eulerian(ALE) 型解法で計算される ことが一般的である.この理由として，ラグランジュ型 解法や ALE 型解法は固体界面を高精度に追跡できるこ と, 経路依存性のある固体構成則の計算が容易である こと等があげられる。しかし，このような固体と流体 で異なる数值解法や解析メッシュを用いた連成解析に は, 次のような課題がある. 第一に, 数值解法や解析 メッシュの異なるソルバー間でのデータの交換やマッピ ングに時間や労力を要する点である. 計算規模が大き くなるほど, データの交換やマッピングに要する時間 と労力も大きくなる．第二に, ラグランジュ型解法や ALE 型解法では固体形状が複雑になるほど，解析メッ シュ生成に多くの時間やノウハウが必要となる点であ る. 第三に, ラグランジュ型解法や ALE 型解法では固 体の大変形やトポロジー変化が生じた場合, メッシュの 数值的健全性を維持することが難しい点である.

以上のような背景から, 既往の研究では, 固体と流 体の双方をオイラー型解法で解析する手法が提案され ている. 杉山ら ${ }^{1)}$ は, 有限差分法に基づく完全オイラー
型の固体-流体連成解析法を提案している．また，著者 ら2) は, 有限要素法に基づく完全オイラー型の固体-流 体連成解析法を提案している。 これらのように, 固体 と流体の双方をオイラー型解法で解析する手法は, 固 体-流体連成問題の中でも特に, 大変形や破断を伴う固 体や自由移動境界を有する流体など非線形性が強い問 題に有効である ${ }^{1) 2}$. ただし, これらの手法は一様な直 交メッシュに基づく手法であるため, 複雑な形状を有す る固体を捕捉するには多大な計算コス卜を要する。そ のため既存の研究では, 形状が複雑な固体と流体の連 成解析ではなく, 血流解析などの比較的単純な形状の 固体と流体の連成解析に適用されている33).

一方，近年の数值流体力学分野では，メッシュの局 所的細分化が可能で並列化効率に優れたビルディング キューブ法 (Building Cube Method, BCM) ${ }^{4}$ ) が注目を集 めている.ビルディングキューブ法は階層型直交メッ シュ法の一種であり, 解析領域はキューブと呼ばれる 立方体領域に分割された後（図-1）, 各キューブは同数 のセルで等間隔に分割される. 局所的に細かいキュー ブを配置することができるため複雑な形状を有する固 体界面の捕捉が容易である.さらに, 各キューブは同 数の直交等間隔セルで分割されているため, シンプル なアルゴリズムを保つことができ, 並列化効率を向上 


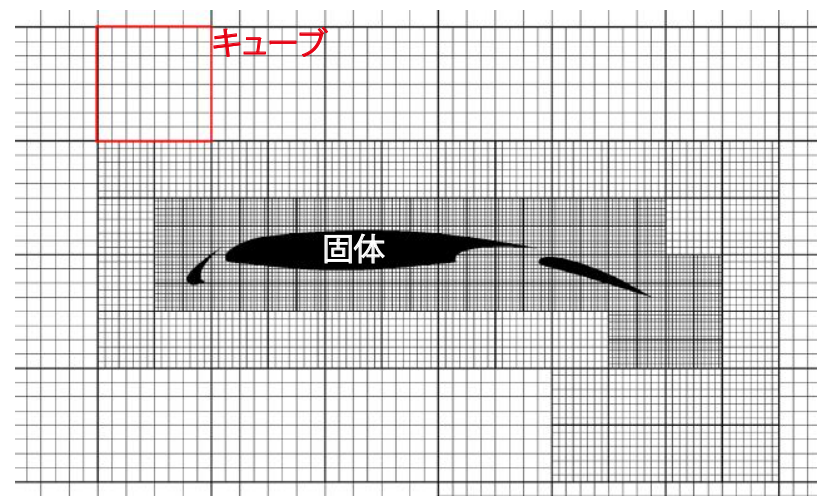

図-1 ビルディングキューブ法におけるキューブ分割の例

させやすい4).

そこで本研究では, 複雑な形状を有する固体と流体 の大規模な連成解析を可能とするため, メッシュの局 所的細分化が可能で並列化効率に優れたビルディング キューブ法による完全オイラー型固体-流体連成解析法 を提案する．特に，大変形や破断を伴う固体や自由移 動境界を有する流体など非線形性が強い固体-流体連成 問題を将来的な解析対象に想定する. 本論文では, 研 究の第一段階として, 大変形解析に適用可能な非圧縮 性ネオフック体と非压縮性ニュートン流体で構成され る系を仮定し，数值解析スキームの提案とその妥当性 検証を行う.

\section{2. 基礎方程式}

\section{（1）連続の式と運動方程式の体積平均化}

オイラー型解法で複数の物質を取り扱う場合, 一つの 計算セルに複数の物質が存在し得る. そこで本研究では, 非圧縮性の仮定の下で固体と流体の基礎方程式を体積平 均化した方程式を用いる ${ }^{12)}$. いま, 3 次元ユークリッド 空間内の検查体積 $(x-\Delta x / 2 \leq \bar{x} \leq x+\Delta x / 2, y-\Delta y / 2 \leq$ $\bar{y} \leq y+\Delta y / 2, \quad z-\Delta z / 2 \leq \bar{z} \leq z+\Delta z / 2)$ に存在する複数 の物質に対する基礎方程式を考える。ここで, 検査体 積内で物質 $i$ の存在する領域を $\Omega_{i}$ としたとき,

$$
I_{i}(x, y, z)= \begin{cases}1 & \text { if }(x, y, z) \in \Omega_{i} \\ 0 & \text { if }(x, y, z) \notin \Omega_{i}\end{cases}
$$

なる指示関数を定義する.すなわち，この関数は検査 体積内において物質 $i$ が存在する領域では 1 , 存在しな い領域では 0 の值をとる. 指示関数 (1)を用いれば, 検 査体積に存在する $n$ 種類の非圧縮性物質に対する連続 の式と運動方程式はそれぞれ次式で与えられる。

$$
\sum_{i=1}^{n} I_{i} \nabla \cdot \boldsymbol{v}_{i}=0
$$

$$
\sum_{i=1}^{n} I_{i} \rho_{i} \frac{D \boldsymbol{v}_{i}}{D t}=\sum_{i=1}^{n} I_{i} \nabla \cdot \boldsymbol{\sigma}_{i}+\left(\sum_{i=1}^{n} I_{i} \rho_{i}\right) \boldsymbol{b}
$$

ここで, $\boldsymbol{v}_{i}$ は物質 $i$ の速度, $\rho_{i}$ は物質 $i$ の質量密度, $\sigma_{i}$ は物質 $i$ の Cauchy 応力, $\boldsymbol{b}$ は体積力である. 式 (2)(3) にそれぞれ体積平均化操作を施すことにより, 次式が 得られる112).

$$
\begin{gathered}
\nabla \cdot \boldsymbol{v}_{\text {mix }}=0 \\
\rho_{\text {mix }}\left(\frac{\partial \boldsymbol{v}_{\text {mix }}}{\partial t}+\left(\boldsymbol{v}_{\text {mix }} \cdot \nabla\right) \boldsymbol{v}_{\text {mix }}\right)=\nabla \cdot \boldsymbol{\sigma}_{\text {mix }}+\rho_{\text {mix }} \boldsymbol{b}
\end{gathered}
$$

ここで, $\boldsymbol{v}_{\text {mix }}, \rho_{\text {mix }}, \sigma_{\text {mix }}$ はそれぞれ以下のように定義 される.

$$
\begin{gathered}
\boldsymbol{v}_{\text {mix }}=\sum_{i=1}^{n} \phi_{i} \overline{\boldsymbol{v}}_{i} \\
\rho_{\text {mix }}=\sum_{i=1}^{n} \phi_{i} \rho_{i} \\
\boldsymbol{\sigma}_{\text {mix }}=\sum_{i=1}^{n} \phi_{i} \overline{\boldsymbol{\sigma}}_{i}
\end{gathered}
$$

式 (6)(7)(8) において, $\phi_{i}$ は検查体積中の物質 $i$ の体積 率であり, 指示関数 (1) を用いて

$$
\phi_{i}=\frac{1}{\Delta x \Delta y \Delta z} \int_{x-\Delta x / 2}^{x+\Delta x / 2} \int_{y-\Delta y / 2}^{y+\Delta y / 2} \int_{z-\Delta z / 2}^{z+\Delta z / 2} I_{i}(\bar{x}, \bar{y}, \bar{z}) d \bar{x} d \bar{y} d \bar{z}
$$

で定義される. また，式(6)における $\overline{\boldsymbol{v}}_{i}$ は物質 $i$ の存在 する領域 $\Omega_{i}$ における $v_{i}$ の体積平均値, 式 (8)における $\bar{\sigma}_{i}$ は物質 $i$ の存在する領域 $\Omega_{i}$ における $\sigma_{i}$ の体積平均 值であり，それぞれ次式で定義される。

$$
\begin{aligned}
& \overline{\boldsymbol{v}}_{i}=\frac{1}{\phi_{i}}\left(\frac{1}{\Delta x \Delta y \Delta z} \int_{x-\Delta x / 2}^{x+\Delta x / 2} \int_{y-\Delta y / 2}^{y+\Delta y / 2} \int_{z-\Delta z / 2}^{z+\Delta z / 2} I_{i} \boldsymbol{v}_{i} d \bar{x} d \bar{y} d \bar{z}\right) \\
& \overline{\boldsymbol{\sigma}}_{i}=\frac{1}{\phi_{i}}\left(\frac{1}{\Delta x \Delta y \Delta z} \int_{x-\Delta x / 2}^{x+\Delta x / 2} \int_{y-\Delta y / 2}^{y+\Delta y / 2} \int_{z-\Delta z / 2}^{z+\Delta z / 2} I_{i} \sigma_{i} d \bar{x} d \bar{y} d \bar{z}\right)
\end{aligned}
$$

本研究の数值計算においては, 検査体積 $(x-\Delta x / 2 \leq$ $\bar{x} \leq x+\Delta x / 2, \quad y-\Delta y / 2 \leq \bar{y} \leq y+\Delta y / 2, \quad z-\Delta z / 2 \leq \bar{z} \leq$ $z+\Delta z / 2)$ は一つの計算セル, 検査体積中の物質 $i$ の体 積率 $\phi_{i}$ は VOF 関数に相当する. 式 (4)(5) では, 各物質 の速度 $\boldsymbol{v}_{i}$ を求めるのではなく, 体積平均化された単一 の速度場 $\boldsymbol{v}_{\text {mix }}$ を求める. さらに, 式 (7)(8) の計算では, 物質毎に VOF 関数 $\phi_{i}$, 質量密度 $\rho_{i}$, 構成方程式を与え る.これにより, 固体と流体で別々に基礎方程式を解 く必要がないため, 連成の取り扱いが容易になる2).

\section{(2) オイラー表示における固体変形の記述}

ラグランジュ表示では, 物質点の初期の位置ベクト ル $\boldsymbol{X}$ と現在の位置ベクトル $\boldsymbol{x}$ を用いて固体変形を評価 する．一方，オイラー表示では物質点を追跡しないた め, ラグランジュ表示と同様に固体の変形を評価する ことができない，そこで本研究では，固体の変形指標 として左コーシー・グリーン変形テンソル $\boldsymbol{B}$ に着目し, 
その定義式 $\boldsymbol{B}=\boldsymbol{F} \cdot \boldsymbol{F}^{T}$ の両辺を物質時間微分すること により得られる以下の時間発展式を導入する5).

$$
\frac{D \boldsymbol{B}}{D t}=\boldsymbol{L} \cdot \boldsymbol{B}+\boldsymbol{B} \cdot \boldsymbol{L}^{T}
$$

ここで， $\boldsymbol{L}$ は速度勾配テンソルであり，次式で定義さ れる。

$$
\boldsymbol{L}=\nabla \boldsymbol{v}_{\text {mix }}
$$

式 (12) をオイラー表示すれば次式のようになる.

$$
\frac{\partial \boldsymbol{B}}{\partial t}+\left(\boldsymbol{v}_{\mathrm{mix}} \cdot \nabla\right) \boldsymbol{B}=\boldsymbol{L} \cdot \boldsymbol{B}+\boldsymbol{B} \cdot \boldsymbol{L}^{T}
$$

左コーシー・グリーン変形テンソル $\boldsymbol{B}$ の時間発展式 (14) により，物質点を用いることなくオイラー表示の速度 場から固体変形を記述することができる.ただし，式 (14) の左辺にあるように, $\boldsymbol{B}$ の移流項も評価すること が必要である。

\section{(3) 構成方程式}

本研究では, 固体の構成方程式としては非圧縮性ネ オフック体, 流体の構成方程式としては非圧縮性ニュー トン流体を仮定する. 非圧縮性ネオフック体の構成方 程式は次式で与えられる5).

$$
\boldsymbol{\sigma}=G J^{-\frac{5}{3}}\left\{\boldsymbol{B}-\frac{1}{3}(\operatorname{tr} \boldsymbol{B}) \boldsymbol{I}\right\}-p \boldsymbol{I}
$$

ここで, $G$ はせん断弾性係数, $J$ は体積変化率, $I$ は 2 階の単位テンソル, $p$ は非圧縮性条件から決定される圧 力である. 式 (15) において, 非圧縮性条件より $J=1$ となることより, 本研究では非圧縮性ネオフック体の 構成方程式として次式を用いる。

$$
\boldsymbol{\sigma}=G\left\{\boldsymbol{B}-\frac{1}{3}(\operatorname{tr} \boldsymbol{B}) \boldsymbol{I}\right\}-p \boldsymbol{I}
$$

ただし, 実際の数值計算では $J=1$ が厳密に成立する とは限らないため，Jを陽に計算することも考えられる が, 後述する数值解析例の参照解 ${ }^{16)}$ と同一の構成方程 式とするため, 本論文では $J=1$ として $J$ を陽に計算 しないこととする。一方, 非圧縮性ニュートン流体の 構成方程式は次式で与えられる.

$$
\boldsymbol{\sigma}=2 \mu \boldsymbol{D}-p \boldsymbol{I}
$$

ここで, $\mu$ は粘性係数, $D$ は変形速度テンソル, $p$ は 非圧縮性条件から決定される圧力である.

\section{3. 数值解析手法}

(1) フラクショナル・ステップ法

本研究では, 基礎方程式を MAC 法系の解法のひとつ であるフラクショナル・ステップ法6)を使って速度場と 圧力場を分離して解く. 体積平均化された運動方程式 (5) は，次式のように書き換えられる.

$$
\frac{\partial \boldsymbol{v}_{\text {mix }}}{\partial t}+\left(\boldsymbol{v}_{\text {mix }} \cdot \nabla\right) \boldsymbol{v}_{\text {mix }}=-\frac{1}{\rho_{\text {mix }}} \nabla p+\frac{1}{\rho_{\text {mix }}} \nabla \cdot \sigma_{\text {mix }}^{\prime}+\boldsymbol{b}
$$

ここで $\sigma_{\text {mix }}^{\prime}$ は $\sigma_{\text {mix }}$ の偏差成分である. 式 (18) に時刻 $n$ に対してオイラー前進差分を適用し, フラクショナル ステップ法に従い速度場と圧力場に分離すれば, 次式 が得られる。

$$
\begin{gathered}
\frac{\boldsymbol{v}_{\text {mix }}^{*}-\boldsymbol{v}_{\text {mix }}^{n}}{\Delta t}+\left(\boldsymbol{v}_{\text {mix }}^{n} \cdot \nabla\right) \boldsymbol{v}_{\text {mix }}^{n}=\frac{1}{\rho_{\text {mix }}} \nabla \cdot \sigma_{\text {mix }}^{\prime n}+b^{n} \\
\frac{\boldsymbol{v}_{\text {mix }}^{n+1}-\boldsymbol{v}_{\text {mix }}^{*}}{\Delta t}=-\frac{1}{\rho_{\text {mix }}} \nabla p^{n+1}
\end{gathered}
$$

ここで $\boldsymbol{v}_{\mathrm{mix}}^{*}$ は, 物理的な速度とは異なる中間的な解と いう意味で中間速度と呼ばれ, 速度 $\boldsymbol{v}_{\text {mix }}^{n+1}$ の予測子であ る. 一方, 式 (20) の両辺の発散を取り, 時刻 $n+1$ でも 連続の式 (4) が成立することにより, 以下の圧力ポアソ ン方程式が得られる.

$$
\nabla \cdot\left(\frac{1}{\rho_{\operatorname{mix}}} \nabla p^{n+1}\right)=\frac{1}{\Delta t} \nabla \cdot v^{*}
$$

また，式 (20) は次式のように書き換えられる.

$$
\boldsymbol{v}_{\text {mix }}^{n+1}=\boldsymbol{v}_{\text {mix }}^{*}-\frac{\Delta t}{\rho_{\text {mix }}} \nabla p^{n+1}
$$

以上を整理すれば，フラクショナル・ステップ法では次 の 3 段階で速度と圧力が計算される.

1. 式 (19) より中間速度 $v_{\text {mix }}^{*}$ を計算する.

2. 中間速度 $\boldsymbol{v}_{\text {mix }}^{*}$ を用いて, 圧力ポアソン方程式 (21) より圧力 $p^{n+1}$ を計算する。

3. 圧力 $p^{n+1}$ を用いて, 速度修正式 (22)より中間速度 $\boldsymbol{v}_{\text {mix }}^{*}$ を速度 $\boldsymbol{v}_{\text {mix }}^{n+1}$ に更新する.

この後, 左コーシー・グリーン変形テンソル $\boldsymbol{B}$ の時間 発展式とVOF 関数 $\phi$ の移流方程式をそれぞれ以下のよ うに計算する。

$$
\begin{gathered}
\boldsymbol{B}^{n+1}=\boldsymbol{B}^{n}-\Delta t\left(\boldsymbol{v}_{\text {mix }}^{n} \cdot \nabla\right) \boldsymbol{B}^{n}+\Delta t\left\{\boldsymbol{L}^{n} \cdot \boldsymbol{B}^{n}+\boldsymbol{B}^{n} \cdot\left(\boldsymbol{L}^{T}\right)^{n}\right\} \\
\phi^{n+1}=\phi^{n}-\Delta t\left(\boldsymbol{v}_{\text {mix }}^{n} \cdot \nabla\right) \phi^{n}
\end{gathered}
$$

ただし, 左コーシー・グリーン変形テンソル $\boldsymbol{B}$ の数值 拡散による計算不安定を避けるため, VOF 関数が閾值 $\phi_{\min }$ 未満の領域を固体が存在しない領域とみなして, 次 式のように左コーシー・グリーン変形テンソル $\boldsymbol{B}$ を初 期化する操作を行う.

$$
\boldsymbol{B}^{n+1}= \begin{cases}\boldsymbol{B}^{n+1} & \text { if } \phi^{n+1} \geq \phi_{\min } \\ \boldsymbol{I} & \text { if } \phi^{n+1}<\phi_{\min }\end{cases}
$$

ここで, $\boldsymbol{I}$ は 2 階の単位テンソルであり, 本研究では閾 值 $\phi_{\min }$ に 0.01 から 0.1 の間の值を設定する. そして最 後に, 固体と流体の偏差応力をそれぞれ以下のように 計算し, 偏差応力 $\sigma_{\text {mix }}^{\prime n+1}$ を求める.

$$
\begin{gathered}
\boldsymbol{\sigma}_{\mathrm{s}}^{\prime n+1}=G\left\{\boldsymbol{B}^{n+1}-\frac{1}{3}\left(\operatorname{tr} \boldsymbol{B}^{n+1}\right) \boldsymbol{I}\right\} \\
\boldsymbol{\sigma}_{\mathrm{f}}^{\prime n+1}=2 \mu \boldsymbol{D}^{n+1} \\
\boldsymbol{\sigma}_{\mathrm{mix}}^{\prime n+1}=\boldsymbol{\sigma}_{\mathrm{s}}^{\prime n+1} \phi^{n+1}+\boldsymbol{\sigma}_{\mathrm{f}}^{\prime n+1}\left(1-\phi^{n+1}\right)
\end{gathered}
$$

ここで, 物質数 $i=2$ として, 固体の偏差応力を $\sigma_{\mathrm{s}}^{\prime}$, 流 体の偏差応力を $\sigma_{\mathrm{f}}^{\prime}$ と表記している. また, 固体領域の 
VOF 関数を $\phi$ とした。そのため流体領域の VOF 関数 は $(1-\phi)$ で表される. なお, 運動方程式 (19), 左コー シー・グリーン変形テンソルの時間発展式 (23), VOF 関数の移流方程式 (31) は, 2 次のアダムス・バッシュ フォース法により時間積分される. これらの具体的な 式はそれぞれ以下の通りである.

$$
\begin{gathered}
\boldsymbol{v}_{\text {mix }}^{*}=\boldsymbol{v}_{\text {mix }}^{n}+\frac{3}{2} \Delta t\left(-\left(\boldsymbol{v}_{\text {mix }}^{n} \cdot \nabla\right) \boldsymbol{v}_{\text {mix }}^{n}+\frac{1}{\rho_{\text {mix }}} \nabla \cdot \boldsymbol{\sigma}_{\text {mix }}^{\prime n}+\boldsymbol{b}^{n}\right) \\
-\frac{1}{2} \Delta t\left(-\left(\boldsymbol{v}_{\text {mix }}^{n-1} \cdot \nabla\right) \boldsymbol{v}_{\text {mix }}^{n-1}+\frac{1}{\rho_{\text {mix }}} \nabla \cdot \boldsymbol{\sigma}_{\text {mix }}^{\prime n-1}+\boldsymbol{b}^{n-1}\right) \\
\boldsymbol{B}^{n+1}=\boldsymbol{B}^{n}+\frac{3}{2} \Delta t\left\{-\left(\boldsymbol{v}_{\mathrm{mix}}^{n} \cdot \nabla\right) \boldsymbol{B}^{n}+\boldsymbol{L}^{n} \cdot \boldsymbol{B}^{n}+\boldsymbol{B}^{n} \cdot\left(\boldsymbol{L}^{T}\right)^{n}\right\} \\
-\frac{1}{2} \Delta t\left\{-\left(\boldsymbol{v}_{\mathrm{mix}}^{n-1} \cdot \nabla\right) \boldsymbol{B}^{n-1}+\boldsymbol{L}^{n-1} \cdot \boldsymbol{B}^{n-1}+\boldsymbol{B}^{n-1} \cdot\left(\boldsymbol{L}^{T}\right)^{n-1}\right\} \\
\phi^{n+1}=\phi^{n}+\frac{3}{2} \Delta t\left\{-\left(\boldsymbol{v}_{\mathrm{mix}}^{n} \cdot \nabla\right) \phi^{n}\right\}-\frac{1}{2} \Delta t\left\{-\left(\boldsymbol{v}_{\mathrm{mix}}^{n-1} \cdot \nabla\right) \phi^{n-1}\right\}
\end{gathered}
$$

\section{(2) 空間離散化}

本研究では, アルゴリズムを単純にするため, 基礎 方程式の空間離散化手法としてコロケート変数配置法 に基づく有限体積法を採用する. すなわち, 圧力・速 度 ·応力は同一のセル中心点で定義され, 運動方程式 (19) の移流項と応力の発散項, 速度修正式 (22) の圧力 勾配は 2 次精度中心差分法で離散化される.

圧力ポアソン方程式 (21) は Red/Black オーダリング により色分けされた逐次過緩和法 (Successive Over Relaxation Method, SOR 法) 7) により解く. Red/Black オー ダリングは, 互いに依存しない交互の格子点を色分け し，並列計算機向けに並列処理ができるように改良さ れた手法である. 元の反復式と演算順序が異なるため 厳密には元の解と一致しないが, 大規模並列計算機に は有利な手法である.

ただし，このようなコロケート変数配置法では，隣 接するセルの圧力差を評価できないためにチェッカー ボード状の圧力振動が生じることが知られている. 本 研究では Rhie-Chow 法8)を用いて圧力振動を回避する. Rhie-Chow 法では, 次式ように, セル面 $i+\frac{1}{2}$ の速度 $u_{i+\frac{1}{2}}^{n+1}$ を計算する際に隣接するセル間 (セル $i$ とセル $i+1)$ で 圧力勾配を打ち消す項を導入する ${ }^{8)}$.

$$
u_{i+\frac{1}{2}}^{n+1}=\frac{u_{i+1}^{*}+u_{i}^{*}}{2}-\Delta t\left(\frac{\partial p^{n+1}}{\partial x_{i}}\right)_{i+\frac{1}{2}}
$$

式 (32) は速度の $x$ 成分の計算の場合を示しているが， $y$ 成分, $z$ 成分の計算も同様である.

固体界面はVOF(Volume-of-Fluid) 法9)により捕捉す る. 前述のように, 本研究では固体領域の VOF 関数を $\phi$, 流体領域の VOF 関数を $(1-\phi)$ とし, VOF 関数 $\phi$ の移流 方程式を 5 次精度を有する WENO(Weighted Essentially
Non-Oscillatory polynomial interpolation) スキーム10) に より計算する.

\section{4. ビルディングキューブ法}

本節では, 本研究で用いるビルディングキューブ法4) について説明する.

\section{(1) ビルディングキューブ法の特長}

ビルディングキューブ法は階層型直交メッシュ法の 一種であり, 解析領域はキューブと呼ばれる立方体領 域に分割された後, 各キューブは同数のセルで等間隔 に分割され, キューブ単位でループ処理が行われる.

一般的な適合細分化格子法による並列計算ではデー タ構造が複雑になりやすく, メモリアクセスが不連続 になるため, 計算負荷を均一にするのは容易ではない. 一方, ビルディングキューブ法では, キューブ単位の計 算になるため, メモリアクセスが局所的かつ連続的に なりやすい. 加えて, キューブ単位のループ処理によ り各キューブの計算負荷が均一になるため, 高い並列 化効率を得ることが容易である4)11).

また，ビルディングキューブ法では，セルは各キュー ブ内に自動的に配置されるためメッシュトポロジーは 単純であり, すべてのセルのコネクティビティ情報を 保存する必要がないため, メッシュデータのファイル サイズが低く抑えられ, 計算中のメモリ使用量も低い という利点がある11). さらに, 非構造メッシュと比べ て高速にメッシュを生成できることも利点である ${ }^{11)}$.

\section{(2) キューブのデータ構造}

ビルディングキューブ法では, 解析領域をセルで分 割する前に，まず解析領域をキューブと呼ばれる立方 体領域に分割する. そのキューブで構成されるメッシュ のデータ構造は八分木である (図-2).八分木とは, 3 次元領域を各軸で 2 分割し, 8 つの領域（オクタント） に再帰的に分割する木構造である. キューブは八分木 における最下層のオクタントに対応する.ループ処理 のアルゴリズムを単純化するために, 空間充填曲線の 一種である Z-ordering を用いて，キューブの空間イン デックスを 1 次元配列に格納する（図-3）.

\section{(3) メッシュ生成の手順}

本研究では, 3 次元 CAD データ形式の一種である STL 形式により記述された固体の形状データを用いて, 固 体形状に適合するキューブを生成する。ここでは, 図-5 に示す固体形状を例に説明する.

まず，図-5 の a)に示すように，固体を含む解析領域 サイズを決定し, 図-5のb)に示すように解析領域を粗 

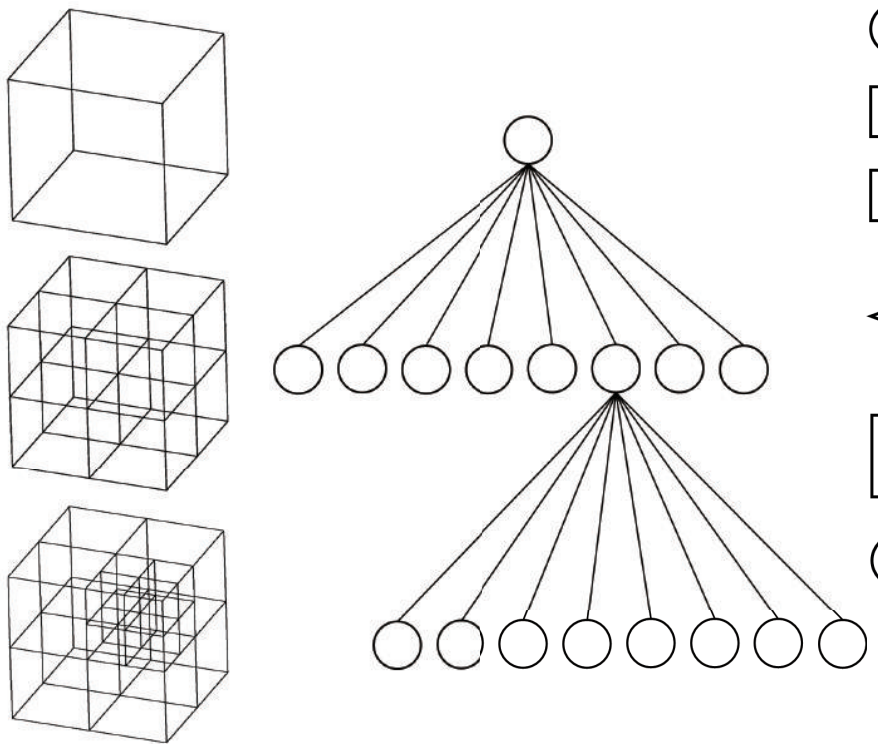

図-2 八分木の概念 (左 : 解析領域の再帰的 8 分割, 右 : 解析 領域の分割に対応する八分木の構造）
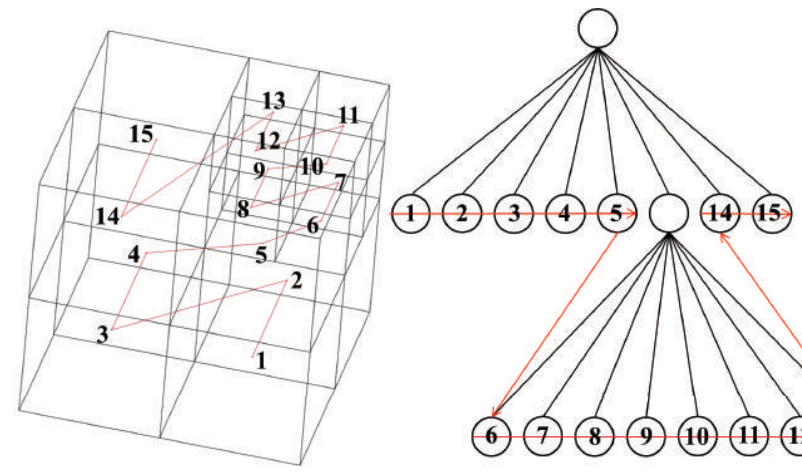

(6) (7) (8) (10) (11) (12) (13)

図-3 Z-ordering によるキューブの空間インデックス（赤線は 空間充填曲線, 番号はキューブの空間インデックスを表 す. 左の分割された立方体における赤線は, 右の八分木 における赤線に対応する.)

いキューブで分割する，そして，固体を含むキューブ に対して，最小キューブサイズ等の事前に設定した閾 值に達するまで，再帰的に分割を繰り返す（図-5 のc) 〜f)）. ただし，図-5 のc) とd)に示すように，キュー ブ分割の過程において，隣接するキューブのサイズは 2 倍または $1 / 2$ 倍になるように分割を行う。これは，4節 (3) で述べるように，サイズが大きく異なるキューブ間 のデータ交換による精度悪化を避けるためである，最 後に, 図-5のf)において, 各キューブを同数のセルで 等間隔に分割することで，メッシュ生成が完了する．以 上のメッシュ生成の流れを示したものが図-4である.

前述のように, 本研究ではVOF 法により固体界面を 捕捉する，そのため，固体形状を表すSTL データを何 らかの方法で各セルの VOF 関数值に変換する必要があ る. そこで本研究では, 小野・俵ら ${ }^{12)}$ の開発したソフ

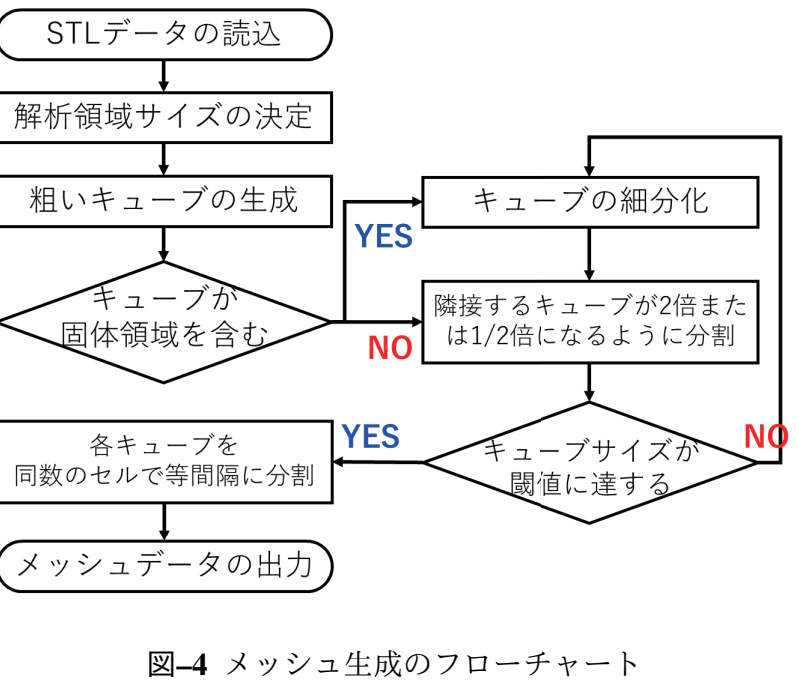

トウェア V-Xgenにより，STL データをボクセルデータ （すなわち各セルにおける VOF 関数值）に変換する.

なお, 本研究では固体の変形・移動に応じてアダプ ティブにメッシュの粗密を変化させる手法は実装して いない，そのため, 現状では固体が変形・移動してく ると予想される領域を事前に細かくメッシングしてい る.しかし, 今後は固体の変形・移動に応じてアダプ ティブにメッシュの粗密を変化させる手法を導入する 予定である.

\section{(4) キューブ間のデータ交換}

ビルディングキューブ法では, キューブ単位でルー プ処理を行うため, キューブ間でデータ交換を行う必 要がある。そのために, 本研究では各キューブに 4 セ ルの緩衝領域 (バンド・セル) を設定し，この緩衝領域 上のセルでデータ交換を行う. 本研究の場合, キュー ブ間で交換するデータは速度, 圧力, 左コーシー・グ リーン変形テンソル, VOF 関数である.ただし, ビル ディングキューブ法では, 隣接するキューブの大きさ が 2 倍または $1 / 2$ 倍のキューブに限定される.したがっ て, データ交換方法は次の 3 種類に分けられる.

1. サイズが同じキューブ間のデータ交換 : データの 補間は必要ない。

2. サイズが異なるキューブ間のデータ交換 (1) : 小さ なキューブから大きなキューブヘデータを補間す る場合.

3. サイズが異なるキューブ間のデータ交換 (2) : 大き なキューブから小さなキューブヘデータを補間す る場合.

上記に対して，既往の研究ではラグランジュ補間を用 いて解を改善した例 ${ }^{13)}$ が報告されているが，本研究で はアルゴリズムを単純にするために下記 a)b) で述べる 補間方法を採用する ${ }^{14)}$. 


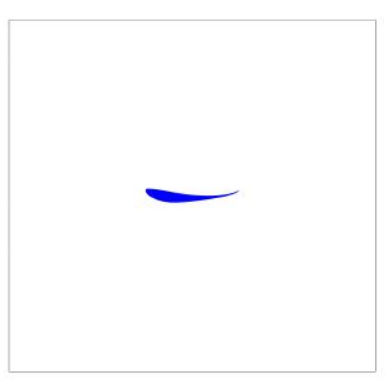

a)

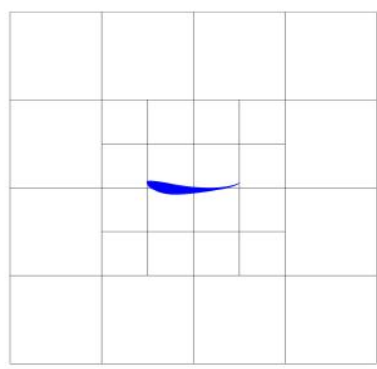

c)

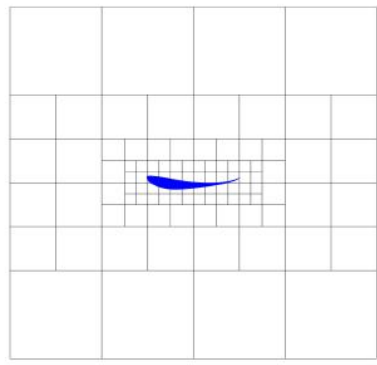

e)

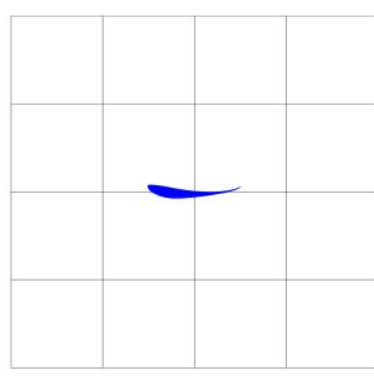

b)

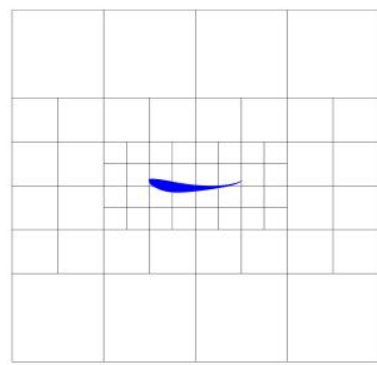

d)

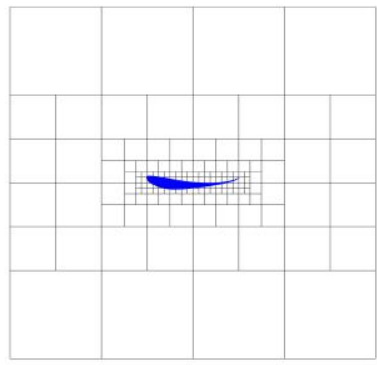

f)
図-5 固体形状に適合するキューブ生成の手順（青色の領域は 固体を表す.)

a) 小さなキューブから大きなキューブへの補間

小さなキューブから大きなキューブへの補間には 1 次 精度補間を用いる.すなわち，バンド・セルにある大き なキューブ内のセル中心の值 $q_{l}$ は, 大きなキューブに隣 接する小さなキューブ内のセル中心の值 $q_{s 1}, q_{s 2}, q_{s 3}, q_{s 4}$ を用いて次式で計算する（図-6）.

$$
q_{l}=\frac{q_{s 1}+q_{s 2}+q_{s 3}+q_{s 4}}{4}
$$

\section{b) 大きなキューブから小さなキューブへの補間}

大きなキューブから小さなキューブへの補間には 0 次補間を用いる.すなわち，バンド・セルにある小さ なキューブ内のセル中心の值 $q_{s 1}, q_{s 2}, q_{s 3}, q_{s 4}$ は，小さな キューブに隣接する大きなキューブ内のセル中心の值 $q_{l}$ を用いて次式で与える（図-7）.

$$
q_{s 1}=q_{s 2}=q_{s 3}=q_{s 4}=q_{l}
$$

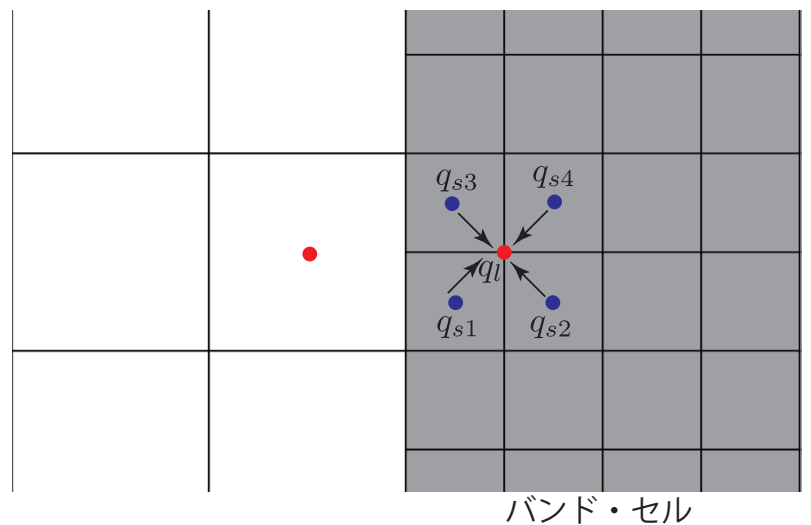

図-6 小さなキューブから大きなキューブへの補間

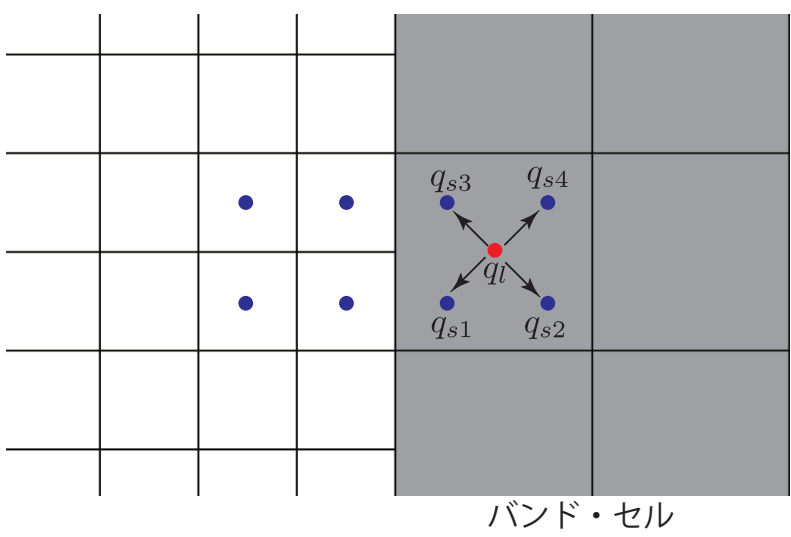

図-7 大きなキューブから小さなキューブへの補間

\section{(5) 並列化方法}

本研究では, キューブ単位のループ処理に対して OpenMPによるスレッド並列処理を適用し，さらにMPI ライブラリを用いたプロセス並列処理も行うハイブリッ ド並列で計算を行う．MPIによる並列計算のための領 域分割には，ParMETIS ライブラリ15)を使用している.

\section{5. 数值解析例}

(1) キャビティ流れ中の超弾性体の 2 次元変形問題 ここでは，キャビティ流れ中で超弾性体を変形させ る問題 ${ }^{16)}$ を取り上げる. 図-8に示すように, 半径 0.2 , 中心座標 $(0.6,0.5)$ の円形の非圧縮性ネオフック体の周 囲に非圧縮性ニュートン流体が満たされており, 解析 領域上面に $u=1.0$ の速度を与え, キャビティ流れを発 生させる. 他の端面はノンスリップ境界条件である。ま た，非圧縮性ネオフック体と非圧縮性ニュートン流体 の物性值はそれぞれ表-1の無次元量を与える.さらに この問題では, 非圧縮性ネオフック体の偏差応力 $\sigma_{s}^{\prime} に$ は粘性力を加えた次式が用いられる.

$$
\boldsymbol{\sigma}_{s}^{\prime}=G\left\{\boldsymbol{B}-\frac{1}{3}(\operatorname{tr} \boldsymbol{B}) \boldsymbol{I}\right\}+2 \mu \boldsymbol{D}
$$


本例題においては， $16 \times 2 \times 16$ セルのキューブで解 析領域を図-9 のように一様に分割する. $y$ 方向を 2 セル で分割して周期境界条件を適用することで 2 次元状態 をモデル化する. 本例題では, $4 \times 4$ キューブ $(64 \times 64$ セル), $8 \times 8$ キューブ $(128 \times 128$ セル $), 16 \times 2 \times 16$ キューブ $(256 \times 256$ セル)， $32 \times 32$ キューブ $(512 \times 512$ セル）の 4 パターンを計算する.

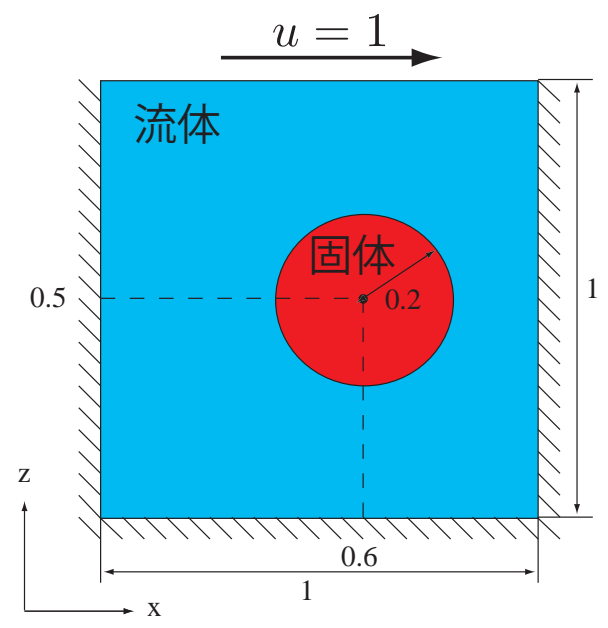

図-8 解析モデル : キャビティ流れ中のネオフック体の 2 次元 変形問題 16 )

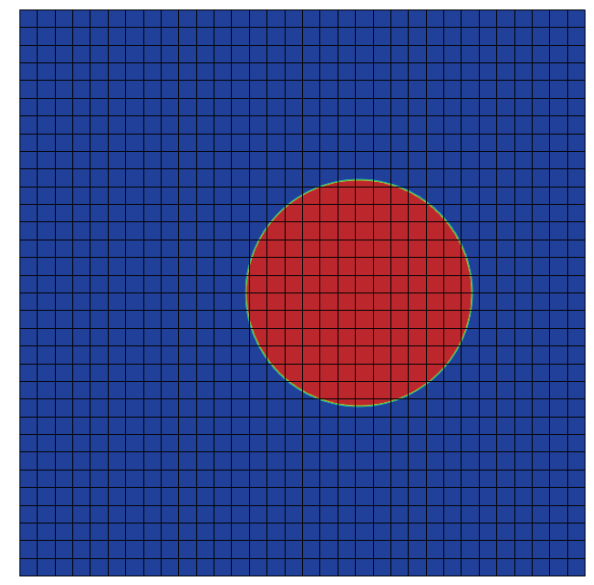

図-9 キューブ分割 $(32 \times 32$ キューブの場合 $)$

\section{a) 参照解との比較と空間解像度に対する収束性}

図-10 は, Zhao ら ${ }^{16)}$ の計算結果と本研究の計算結果 (VOF 值 0.5 の等值線 : $512 \times 512$ セル分割の場合) の固 体変形を比較したものであり, 概ね良い一致を示して いることが確認できる．ただし，Zhao ら ${ }^{16)}$ の結果に対 して, 本手法の結果には誤差がみられる.この原因とし て, VOF 関数や左コーシー・グリーン変形テンソルの 移流による数值拡散の影響が考えられる. また, 図-11 は各解像度における固体界面と固体の重心点を示した ものである，空間解像度に対する収束性を定量的に評
表-1 材料物性

\begin{tabular}{|c|c|}
\hline \multicolumn{2}{|c|}{ 固体：非圧縮性ネオフック体 } \\
\hline 質量密度 $\rho_{\mathrm{s}}$ & 1.0 \\
\hline せん断弾性係数 $G$ & 0.1 \\
\hline \multicolumn{2}{|c|}{ 流体：非圧縮性ニュートン流体 } \\
\hline 質量密度 $\rho_{\mathrm{f}}$ & 1.0 \\
\hline 粘性係数 $\mu$ & 0.01 \\
\hline
\end{tabular}

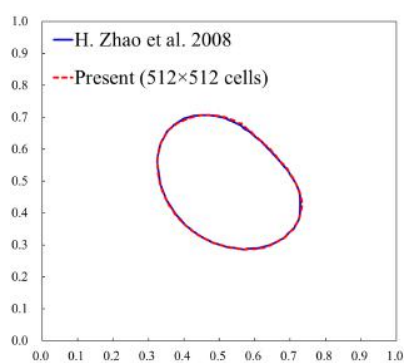

a) $\mathrm{t}=1.17$

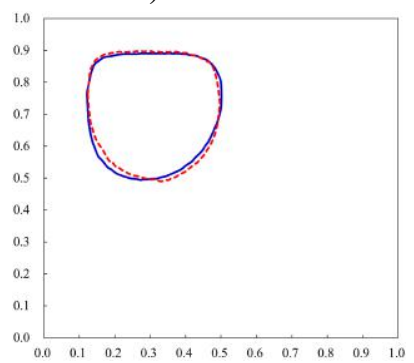

c) $t=3.52$

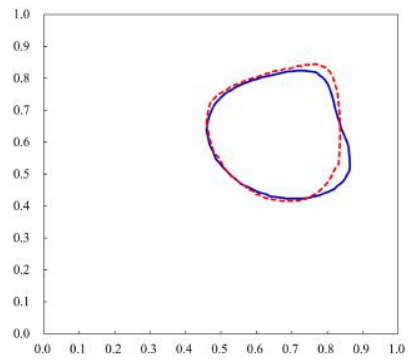

e) $t=7.03$

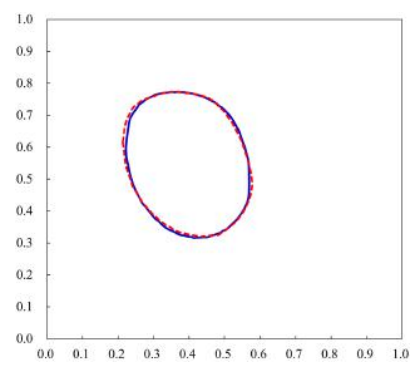

b) $\mathrm{t}=2.34$

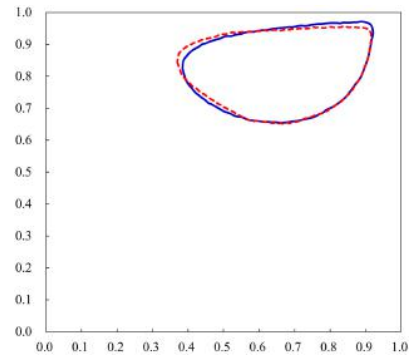

d) $\mathrm{t}=5.86$

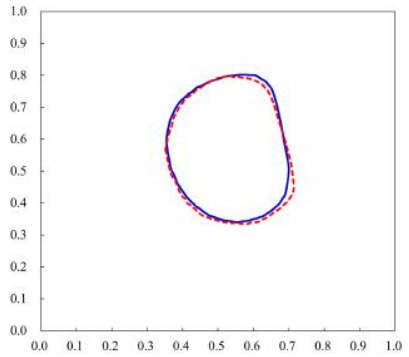

f) $\mathrm{t}=8.20$
図-10 Zhao ら 16) の結果との比較 : 固体変形

価するため, Zhao ら ${ }^{16)}$ の結果に対する固体の重心点の $L^{1}$ 誤差と $L^{2}$ 誤差を各解像度で計算した（図-12）。そ の結果, $L^{1}$ 誤差と $L^{2}$ 誤差は図-12 に示すように収束す ることが確認された。

以上より, 固体変形の比較と空間解像度に対する収 束性の観点から，本解析結果の妥当性が検証されたと 考えられる．なお，Zhao らは流体領域を $128 \times 128$ の 直交メッシュでオイラー的に解き, 固体領域を 74 個の 三角形メッシュでラグランジュ的に解いている ${ }^{16)}$. 本研 究は完全オイラー型の解法であるため, Zhao らの手法 


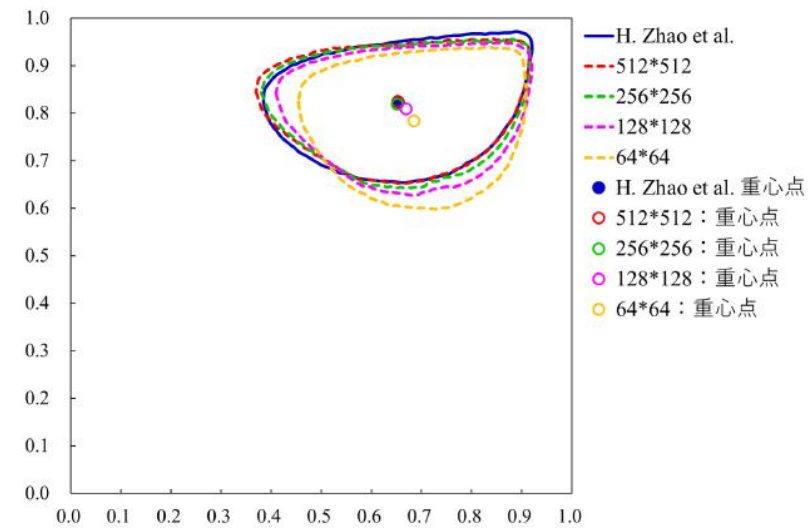

図-11 固体界面（VOF 值 0.5）と固体の重心点

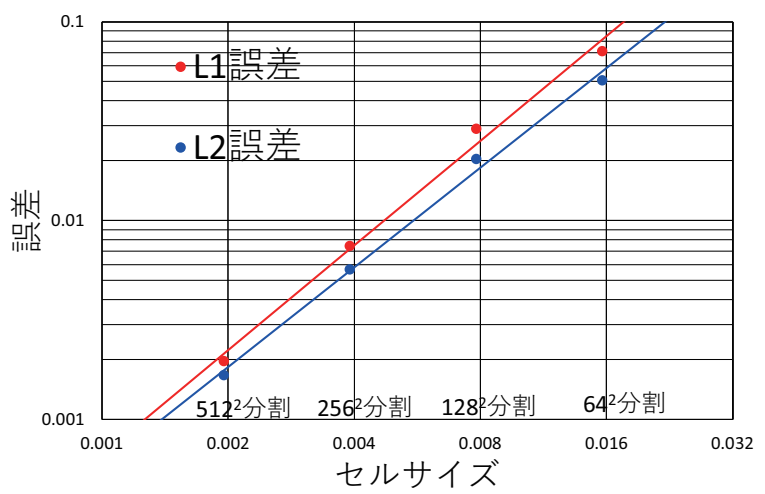

図-12 セルサイズに対する重心点の誤差の収束性

より解像度の高いメッシュを用いる必要があるが, 前 述のように固体と流体を統一的に解ける点は有益であ ると考える。

\section{b) 並列化効率の検証}

次に，本例題で提案手法の並列化効率を検証する. 並 列化効率はウィーク・スケーリングおよびストロング . スケーリングで評価する，使用ハードウェアは東京大 学情報基盤センターの Oakleaf-FX である. Oakleaf-FX は, 富士通 PRIMEHPC FX10 で構成されており, プロ セッサは SPARC64 IXfx で 1 プロセッサに 16 コアが実 装されている，各計算ノードは 1 個のプロセッサとイ ンターコネクトコントローラ, メモリで構成されてお り，インターコネクトは 6 次元メッシュ/トーラス構造 である.

ウィーク・スケーリングにおいて, 並列度 $m$ を基準 とした並列度 $n$ における並列化効率 $\beta_{\text {weak }}$ は次式で定義 される.

$$
\beta_{\text {weak }}=\frac{T_{m}}{T_{n}}
$$

ここで, $T_{m}$ は $m$ コアで計算した 10 ステップに要する 実行時間, $T_{n}$ は $n$ コアで計算した 10 ステップに要する 実行時間である. ウィーク・スケーリングにおいては, 1 コアが担当するセル数を 1024 に固定し， 32 コア（2
ノード）を基準として 32768 コア（2048ノード）まで 計測した（図-13）. 図-13 より, ウィーク・スケーリン グでは, 並列度 32 コアを基準とした並列度 32768 コア における並列化効率 $\beta_{\text {weak }}$ は $93.6 \%$ となることが磼認さ れた。

一方，ストロング・スケーリングにおいては，並列 度 $m$ を基準とした並列度 $n$ における並列化効率 $\beta_{\text {strong }}$ は次式で定義される。

$$
\beta_{\text {strong }}=\frac{m T_{m}}{n T_{n}}
$$

ストロング・スケーリングにおいては, メッシュ分割数 （256×256 キューブ : 4096×2×4096セル）を固定し， 128 コア（8ノード）を基準として 32768 コア（2048 ノード）まで計測した（図-14）。図-14より，ストロン グ・スケーリングでは, 並列度 128 コアを基準とした並 列度 32768 コアにおける並列化効率 $\beta_{\text {strong }}$ は $70.2 \%$ と なることが確認された。従来的な固体解析ソルバーの 並列化効率を考慮すれば，本手法では良好な並列化効 率が得られていると言える.

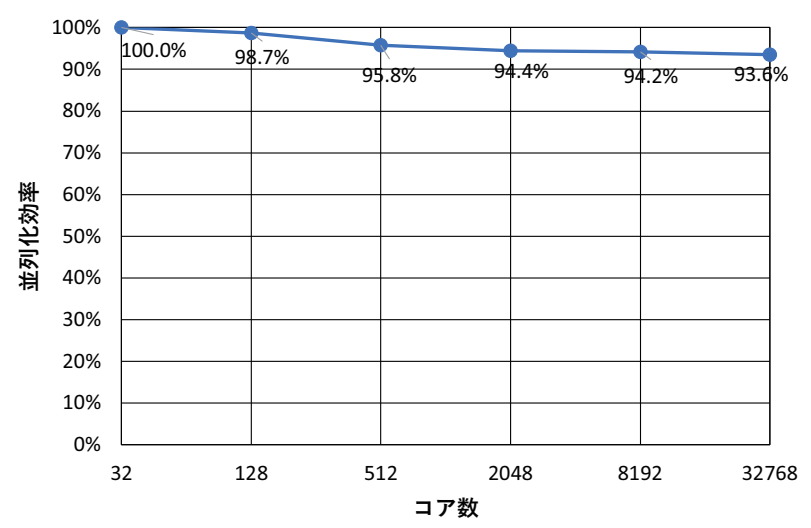

図-13 ウィーク・スケーリングの計測結果

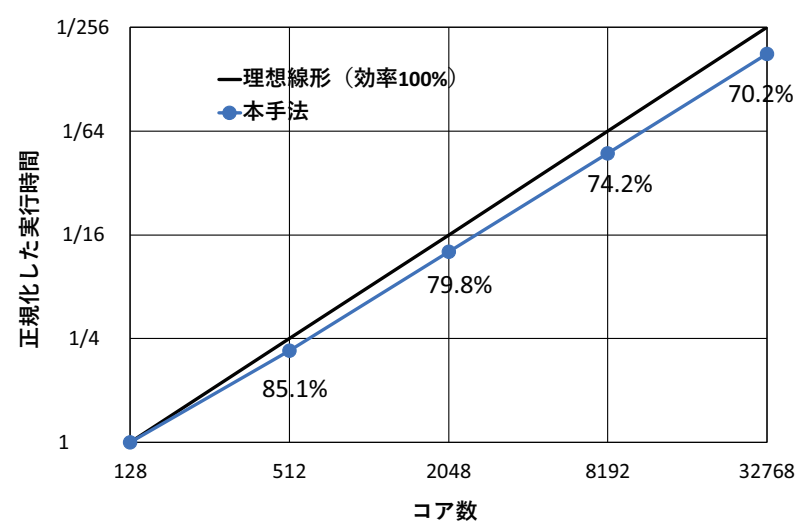

図-14 ストロング・スケーリングの計測結果 


\section{c) 計算コストの内訳}

最後に，本例題における計算コストの内訳を確認す る.メッシュ分割数を $64 \times 64$ キューブ : $1024 \times 2 \times 1024$ セルとした場合，128ノード（2048コア）を用いて 10 ステップに要する演算時間は $19.37 \mathrm{~s}$ ，通信時間は $0.72 \mathrm{~s}$ であった。この演算時間と通信時間の内訳をそれぞれ 図-15 と図-16に示す. 図-15 より, 本手法ではキューブ 間のデータ交換に最も長い演算時間が費やされている が，この演算と同時に通信も行うことで効率化を図っ ている.

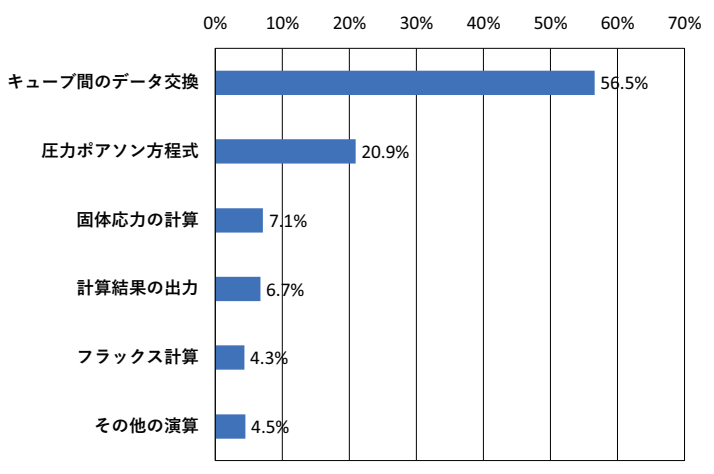

図-15 演算時間の内訳（128 ノード使用時）

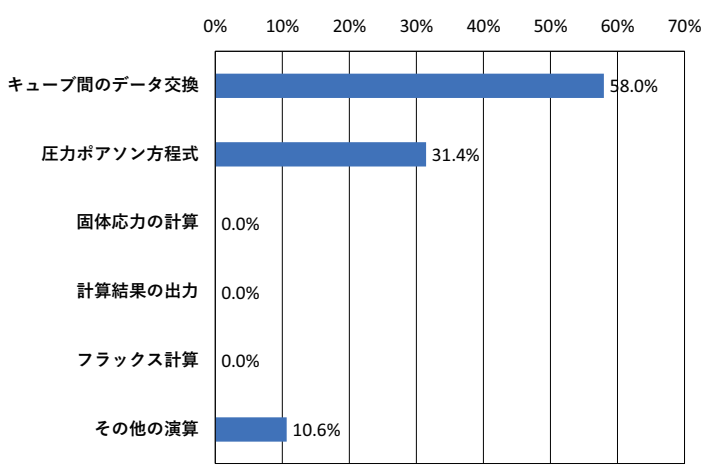

図-16 通信時間の内訳（128 ノード使用時）

\section{(2) 流体中の Stanford bunny の 3 次元変形問題}

次の例題として, 複雑形状を有する固体と流体の連 成問題への適用可能性を検証するため, 非圧縮性ニュー トン流体中で Stanford bunny ${ }^{17)}{ }^{18)}$ 形状の非圧縮ネオフッ ク体を変形させる問題を考える. $1 \times 1 \times 1$ の立方体領域 中に Stanford bunny を配置し, Stanford bunny 形状の非 圧縮性ネオフック体とその周囲を満たす非圧縮性ニュー トン流体の物性值として，それぞれ表-2 の無次元量を 与える. 解析領域端面はスリップ境界条件とし, 文献16) の例題と同様に $t=0.00$ において次の初速度を与える.

$$
\begin{gathered}
u=+0.1 \pi \sin (2 \pi x) \cos (2 \pi z) \\
v=-0.1 \pi \cos (2 \pi x) \sin (2 \pi z) \\
w=0
\end{gathered}
$$

表-2 材料物性

\begin{tabular}{cc}
\hline 固体 : 非压縮性ネオフック体 & \\
\hline 質量密度 $\rho_{\mathrm{s}}$ & 1.0 \\
せん断弾性係数 $G$ & 1.0 \\
\hline 流体 : 非圧縮性ニュートン流体 \\
\hline 質量密度 $\rho_{\mathrm{f}}$ & 1.0 \\
粘性係数 $\mu$ & 0.001 \\
\hline
\end{tabular}

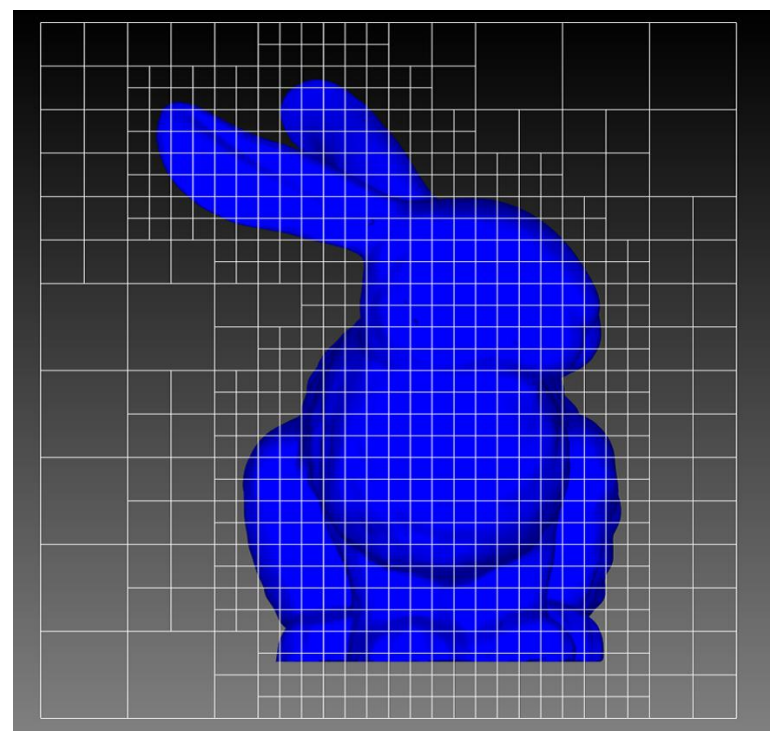

図-17 キューブ分割（最小セルサイズ $1 / 512$ の場合）

本例題においては, $16 \times 16 \times 16$ セルを持つキューブ で解析領域を分割し, 最小セルサイズが $1 / 64,1 / 128$, 1/256，1/512の 4 パターンを計算する. 図-17 は最小セ ルサイズが $1 / 512$ の場合のキューブ分割である. 図-17 に示すように，固体から離れた領域に大きなキューブ を配置し, 固体領域近傍には集中的に細かいキューブ を配置している。

図-18 は各時刻における Stanford bunny の変形とミー ゼス応力分布を示したものであり, 耳のように急峻な 界面を持つ部分など複雑な形状の固体変形を捕捉でき ていることが確認できる. 図-18より, 応力分布に不自 然な空間的な振動は生じておらず，変形が大きい領域 に高い応力が生じており, 定性的に問題がないと思わ れる数值解が得られていると言える.ただし, 固体の 応力分布の定量的な検証は今後の課題である.

ここでは, 計算結果の妥当性を検証するため, 系全 体のエネルギ収支を確認する. 運動エネルギ $E_{\mathrm{k}}$, 固体 のひずみエネルギ $E_{\mathrm{s}}$, 流体の粘性による散逸エネルギ $E_{\mathrm{disp}}$, 系全体のエネルギ $E_{\mathrm{total}}$ はそれぞれ以下のように 
与えられる。

$$
\begin{gathered}
E_{\mathrm{k}}=\frac{1}{2} \int_{\Omega} \boldsymbol{v}^{2} d V \\
E_{\mathrm{S}}=\int_{\Omega} \frac{G}{2}(\operatorname{tr} \boldsymbol{B}-3) d V \\
\dot{E}_{\mathrm{disp}}=\int_{\Omega} \mu \boldsymbol{L}: \boldsymbol{L} d V \\
E_{\text {total }}(t)=E_{k}(t)+E_{s}(t)+\int_{0}^{t} \dot{E}_{\mathrm{disp}}(s) d s
\end{gathered}
$$

式 (41)-(44)を用いて系のエネルギ収支を計算した結果 を図-19に示す. 図-19より, 初速度として与えた運動エ ネルギが固体のひずみエネルギと流体の粘性による散逸 エネルギに変換されている様子が確認できる. $t=1.00$ における系の全エネルギ保存率は図-20 の通りであり, 空間解像度を上げるに従ってエネルギ保存率が $100 \%$ に 漸近していることが確認できる. ただし, 図-19より散 逸エネルギが一定值に収束しているか否かを判断する ことはできない，したがって，今後の課題として，散 逸エネルギの空間収束性について他の数值解析例にお いて検証を行う必要があると考える.

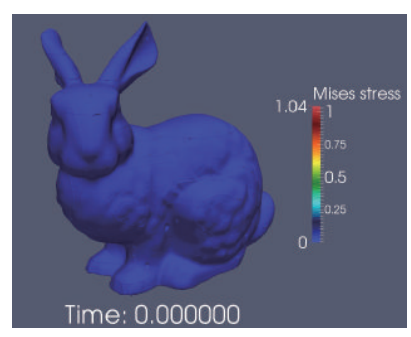

a) $\mathrm{t}=0.00$

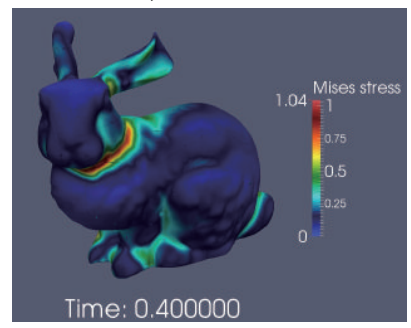

c) $\mathrm{t}=0.40$

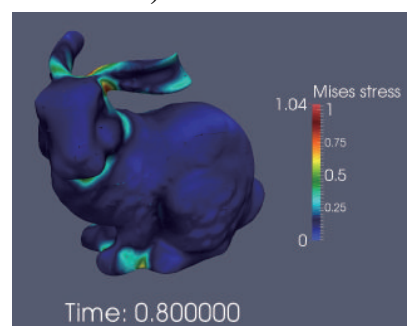

e) $t=0.80$

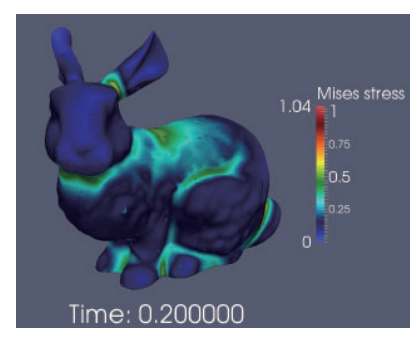

b) $\mathrm{t}=0.20$

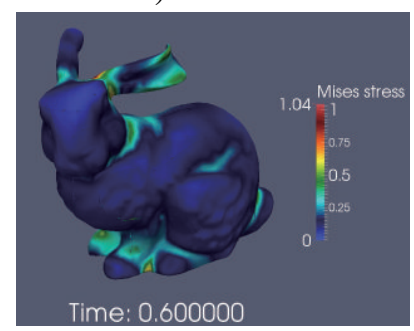

d) $t=0.60$

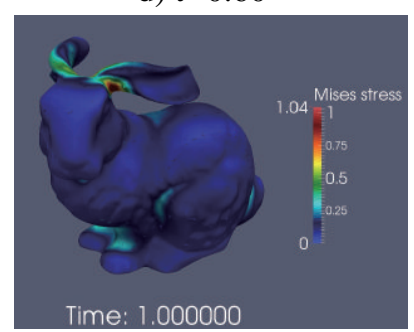

f) $\mathrm{t}=1.00$
図-18 変形とミーゼス応力分布（最小セルサイズ 1/512 の 場合）

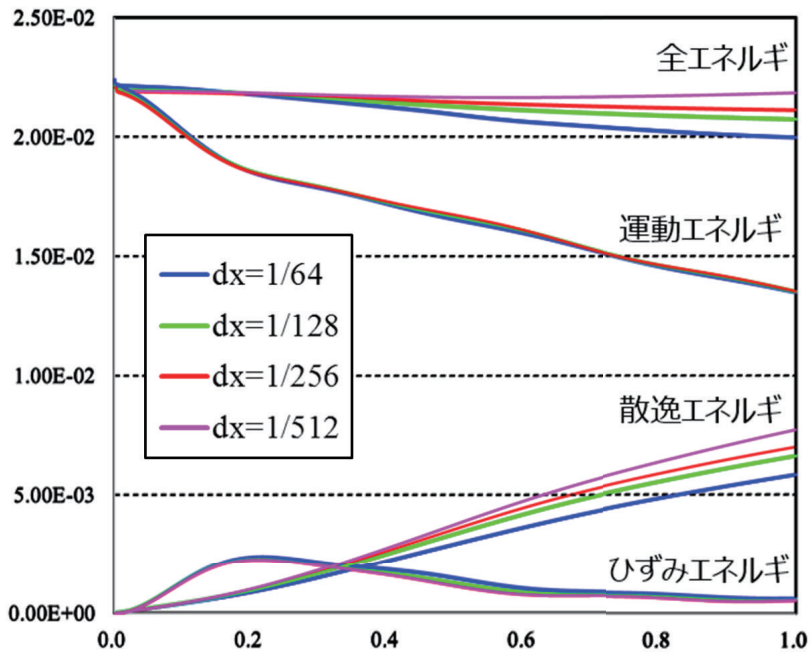

図-19 系全体のエネルギ収支

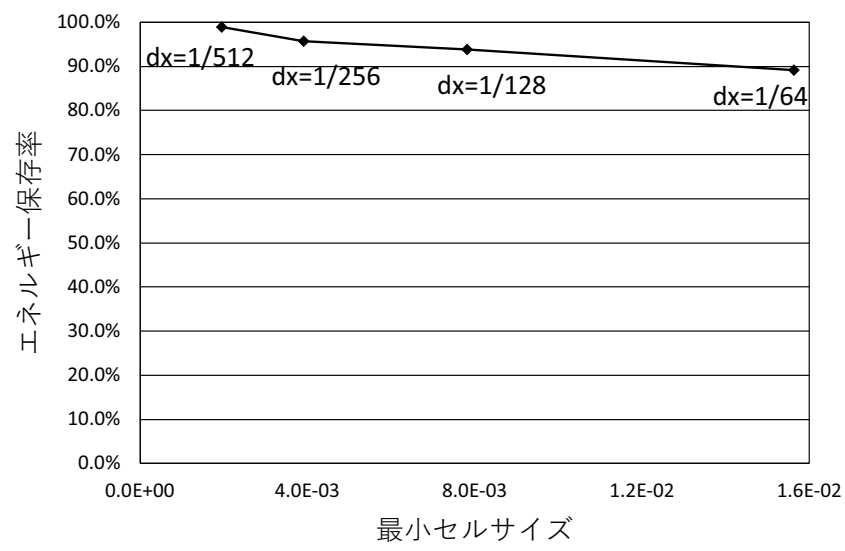

図-20 最小セルサイズ $d x$ に対する系の全エネルギ保存率 $(t=$ 1.00)

\section{6. 結言}

大変形や破断を伴う固体や自由移動境界を有する流 体など非線形性が強い固体-流体連成問題に有効な既往 の完全オイラー型の固体-流体連成解析法は，一様な直 交メッシュに基づく手法であるため，その応用範囲は比 較的単純な形状の固体と流体の連成解析に限られてき た。そこで本研究では，複雑な形状を有する固体と流 体の大規模な連成解析を可能とするため，メッシュの 局所的細分化が可能で並列化効率に優れたビルディン グキューブ法による完全オイラー型固体-流体連成解析 法を提案した.

そして，キャビティ流れ中の円盤の 2 次元変形問題, および流体中で複雑形状を有する固体 (Stanford bunny) を変形させる問題において，固体変形・エネルギの保 存性・空間解像度に対する収束性の観点から提案手法 
の妥当性を検証した．また，ウィーク・スケーリングで は並列度 32 コアを基準とした並列度 32768 コアにおけ る並列化効率は $93.6 \%$ ，ストロング・スケーリングでは 並列度 128 コアを基準とした並列度 32768 コアにおけ る並列化効率は $70.2 \%$ となることを確認した。

今後は, 固体の変形・移動等に応じて時々刻々とメッ シュ解像度を変化させることが可能なアダプティブ・ メッシュ・リファインメント (Adaptive mesh refinement) 手法の導入, 計算コードのチューニングによる並列化 効率のさらなる向上，および産業上実用的な問題へ本 手法を適用することが課題である.

謝辞： 本研究は, 文部科学省フラッグシップ 2020 プ ロジェクト・ポスト「京」重点課題 8 「近未来型ものづ くりを先導する䪊的設計・製造プロセスの開発」の一 環として実施したものである. また本論文に示した数值 計算には, 東京大学情報基盤センターの Oakleaf-FX お よび名古屋大学情報基盤センターの PRIMEHPC FX100 を利用した。ここに記して謝意を表する。

\section{参考文献}

1) Sugiyama, K., Ii, S., Takeuchi, S., Takagi, S., Matsumoto, Y.: A full Eulerian finite difference approach for solving fluid-structure coupling problems, Journal of Computational Physics, Vol.230, No.3, pp.596-627, 2011.

2）岡澤重信, 西口浩司, 田中智行: 自由移動境界を有するボク セル固体流体連成解析, 日本計算工学会論文集, Vol.2014, paper No.20140011, 2014.

3) Takagi, S., Sugiyama, K., Ii, S., Matsumoto, Y.: A review of full Eulerian methods for fluid structure interaction problems, Journal of Applied Mechanics, Vol.79, No.1, pp.010911, 2012.

4) Nakahashi, K: Building-Cube Method for Flow Problems with Broadband Characteristic Length, Computational Fluid Dynamics 2002, Springer Berlin Heidelberg, pp. 7781, 2003.

5) Bonet, J., Wood, R.D.: Nonlinear Continuum Mechanics for Finite Element Analysis, Cambridge University Press, Cambridge, second edition, Chap. 4, 2008.
6) Chorin, A. J.: On the convergence of discrete approximations to the Navier-Stokes equations, Mathematics of computation, Vol.23, No.106, pp.341-353, 1969.

7) Yavneh, I.: On red-black SOR smoothing in multigrid, SIAM Journal on Scientific Computing, Vol.17, No.1, pp.180-192, 1996.

8) Rhie, C. M., Chow, W. L.: Numerical study of the turbulent flow past an airfoil with trailing edge separation, AIAA journal, Vol.21, No.11, pp.1525-1532, 1983.

9) Hirt, C. W., Nichols, B. D.: Volume of fluid (VOF) method for the dynamics of free boundaries Journal of computational physics, Vol.39, No.1, pp.201-225, 1981.

10) Jiang, G. S., Shu, C. W. : Efficient implementation of weighted ENO schemes, Journal of Computational Physics, Vol.126, No.1, pp. 202-228, 1996.

11) Ishida, T., Takahashi, S., Nakahashi, K. : Efficient and robust cartesian mesh generation for building-cube method, Journal of Computational Science and Technology, Vol.2, No.4, pp.435-446, 2008.

12) Tawara, T., Ono, K. : Fast large scale voxelization using a pedigree, The 10th ISGG Conference on Numerical Grid Generation, 2007.

13) Ishida, T.: Study of High-Order/High- Resolution Method for Flow Simulations with Cartesian Grid Method, Ph.D dissertation, Tohoku University, 2011.

14) Onishi, K., Tsubokura, M., Obayashi, S., Nakahashi, K.: Vehicle Aerodynamics Simulation for the Next Generation on the K Computer: Part 2 Use of Dirty CAD Data with Modified Cartesian Grid Approach, SAE International Journal of Passenger Cars-Mechanical Systems, Vol.7, No.201401-0580, pp. 528-537, 2014.

15) Karypis, G., Kumar, V.: A parallel algorithm for multilevel graph partitioning and sparse matrix ordering, Journal of Parallel and Distributed Computing, Vol.48, No. 1, pp. 7195, 1998.

16) Zhao, H., Freund, J. B., Moser, R. D.: A fixed-mesh method for incompressible flow-structure systems with finite solid deformations, Journal of Computational Physics, Vol. 227, No. 6, pp.3114-3140, 2008.

17) Turk, G., Levoy, M: The Stanford 3D Scanning Repository, https://graphics.stanford.edu/data/3Dscanrep/

18) Turk, G., Levoy, M.: Zippered polygon meshes from range images, In Proceedings of the 21st annual conference on Computer graphics and interactive techniques, ACM, pp. 311-318, 1994.

(2017. 6. 23 受付)

Fully Eulerian solid-fluid interaction analysis using hierarchical Cartesian mesh method for large-scale parallel computing

\section{Koji NISHIGUCHI, Rahul BALE, Shigenobu OKAZAWA and Makoto TSUBOKURA}

In this paper, we propose a full Eulerian solid-fluid interaction analysis method using the building cube method, which is capable of achieving high parallel efficiency and generating meshes easily for complex geometry with local mesh refinement. Basic equations of solid and fluid are spatially averaged using volume fractions of each material on the assumption that both solid and fluid are incompressible. The averaged equations are solved using a fractional step method, where the equations are discretized in space using a collocated finite volume method. The VOF method is applied to capture material interfaces and the advection equation of VOF function is computed with the fifth-order WENO scheme. To validate the present approach, we simulate fluid-structure interaction problems, e.g. a deformable disk in a lid-driven cavity, deformation of Stanford bunny in fluid. 